\title{
PENGARUH CITRA MEREK DAN HARGA TERHADAP KEPUTUSAN PEMBELIAN PADA BRAND JEANNE ARTHES PARFUM PT.MATAHARI DEPARTEMENT STORE MALL LEMBUSWANA SAMARINDA
}

\author{
Fitriani \\ Robin Jonathan \\ Adisthy Shabrina Nurqamarani \\ University of 17 Agustus 1945 Samarinda \\ Jl. Ir. H. Juanda No. 80, 75124, Indonesia \\ Fitriyanixxx@yahoo.co.id
}

\begin{abstract}
This research aims to identify: 1) brand image of purchase decision on Jeanne arthes perfume brand, 2) price to purchase result on Jeanne arthes perfume brand, 3) brand image and price to purchase decision of Jeanne arthes perfume brand.

The research population is all customers of perfume brand of Jeanne Arthes PT. Matahari Department Mall Lembuswana Samarinda. Samples are 96 respondents with Unknown population and sample selection using Incidental Sampling technique. Variables in this research are 3 that are brand image, price and purchase decision. Data analysis technique used is multiple linear regressions with classical assumption test and hypothesis testing.

The finding of the researsh shows that brand image and price affect positive and significant to purchase decision on the brand Jeanne Arthes Perfume PT. Matahari Department Store Mall Lembuswana Samarinda. , variable of brand image and price simultaneously have positive and significant effect to purchase decision on Jeanne Arthes perfume brand of PT. Matahari Department Store Mall Lembuswana Samarinda. Forfuther research is expected that the next researcher can use other product brands and/or other independent variables so that more findings are identified.
\end{abstract}

Keywords: Brand Image, Price, and Purchasing Decision.

\section{PENDAHULUAN}

Konsumen saat ini sangatlah

kritis dalam memilih suatu produk, keputusan untuk membeli suatu produk sangat dipengaruhi oleh penilaian akan bentuk kualitas produk tersebut. Tuntutan permintaan akan sebuah produk yang semakin berkualitas membuat perusahaan yang bergerak di berbagai bidang usaha berlomba-lomba meningkatkan kualitas produknya demi mempertahankan citra merek produk yang mereka produksi. Merek mempunyai sifat khas, dan sifat khas inilah yang membedakan produk yang satu berbeda dengan produk yang lainnya, walaupun produknya sejenis. 
Pemilihan parfum di Indonesia sendiri adalah sesuatu yang mudah namun sulit, artinya para konsumen dihadapkan pada banyaknya pilihan yang menyebabkan mereka bingung untuk memilih, karena jika salah memilih dapat berakibat fatal bagi kesehatan kulit, dan aroma pada tubuh.

Jeanne Arthes merupakan salah satu brand parfum yang cukup terkenal di kalangan masyarakat Grasse. Jeanne Arthes merupakan salah satu bagian dari Arthes Group yang berasal dari Perancis. Didirikan pada tahun 1978, Jeanne Arthes memulai perusahaan parfumnya di daerah Grasse. Perusahaan parfum ini mulai memasarkan wewangian pada akhir 1980 di seluruh dunia. Di tahun 1987 akhirnya Jeanne Arthes memutuskan untuk membeli segala fasilitas pabrik di Grasse. Ia pun membangun perusahaan di Grasse dan memulai negosiasi dengan pengecer di seluruh dunia untuk memasarkan produknya. Parfum Jeanne Arthes dipasarkan di Auchan, Leclerc, Magasin U, Carrefour, dan Intermarche.

Pada tahun 2011 Arhes group memulai memasarkan wewangiannya pada PT. Matahari Department Store Mall Lembuswana Samarinda dibawa naungan APS Group. PT. Aneka Prima
Sejati (APS Group) adalah perusahaan yang bergerak dibidang distributor perfume berskala nasional. PT. Matahari Department Store (MDS) adalah sebuah perusahaan ritel yang merupakan pemilik dari jaringan toserba Matahari. Perusahaan ritel ini menawarkan berbagai macam produk fashion, cosmetic, parfum dan peralatan rumah tangga.

\section{TINJAUAN PUSTAKA}

\section{Manajemen dan Manajemen \\ Pemasaran}

Menurut Hasibuan (2009:2), mendefinisikan manajemen adalah suatu proses yang khas yang terdiri dari tindakan-tindakan perencanaan, pengarahan dan pengandalian yang dilakukan untuk menentukan serta mencapai sasaran-sasaran yang telah ditentukan melalui pemanfaatan sumber daya manusia dan sumber-sumber lainnya.

Manajemen pemasaran menurut Kotler dan Keller (2009:62), adalah proses sosial dimana dengan proses itu individu dan kelompok mendapatakan apa yang mereka butuhkan dan inginkan dengan menciptakan, menawarkan, dan secara bebas mempertukarkan produk dan jasa yan bernilai dengan pihak lain. 


\section{Bauran Pemasaran}

Menurut Kotler dan Armstrong

(2012:223), bauran pemasaran

dikelompokkan menjadi 4 antara lain :

1. Product (Produk) adalah kombinasi barang dan jasa yang ditawarkan perusahaan kepada pasar sasaran. Produk yang ditawarkan dapat dalam beberapa model, fitur dan pilihan lainnya.

2. Price (Harga) adalah jumlah uang yang harus dibayarkan pelanggan untuk memperoleh produk. Harga yang diberikan dapat berupa harga eceran, harga diskon, dana harga lainnya. Pemberian harga tersebut dimaksudkan untuk menyesuaikan harga dengan situasi persaingan yang ada dan membawa produk tersebut agar sejalan dengan persepsi pembeli tentang nilai suatu produk.

3. Place (Tempat) atau distribusi meliputi kegiatan perusahaan yang membuat produk tersedia bagi pelanggan sasaran. Tempat ini meliputi proses pendistribusian produk, untuk menyalurkan produk ke konsumen yang potensi untuk melakukan pembelian.

4. Promotion (Promosi) adalah aktivitas menyampaikan manfaat produk dan membujuk pelanggan membelinya. Promosi dilakukan dengan tujuan untuk memberitahukan pelanggan tentang perusahaan dan produk-produknya.

\section{Produk}

Menurut Stanton dalam Buchari Alma (2011:139), produk ialah seperangkat atribut baik berwujud maupun tidak berwujud, termasuk di dalamnya warna, harga, nama baik produk, nama baik pengecer, dan pelayanan pabrik serta pelayanan pengecer yang diterima oleh pembeli guna memuaskan kebutuhan dan keinginannya.

\section{Atribut Produk}

Atribut produk mempunyai pengaruh besar pada persepsi pembeli terhadap produk. Selain membedakan suatu produk dengan produk lain, atribut produk juga harus mampu menjadi suatu daya tarik bagi konsumen. Hal itu disebabkan karena secara fisik atribut produk membawa berbagai macam manfaat yang dibutuhkan dan diinginkan pembeli. Menurut Tjiptono (2010:103), atribut produk adalah unsur-unsur produk yang di pandang penting oleh konsumen dan dasar pengambilan keputusan pembelian. 


\section{Unsur-Unsur Atribut Produk}

Menurut Tjiptono (2010:104-

108), unsur-unsur atribut produk antara lain meliputi:

1. Merk merupakan nama, istilah, tanda, simbol/lambang, desain, warna, gerak, atau kombinasi atribut-atribut produk lainnya yang diharapkan dapat memberikan identitas dan diferensiasi terhadap produk pesaing.

2. Pengemasan (packaging) merupakan proses yang berkaitan dengan perancangan dan pembuatan wadah (container) atau pembungkus (wrapper) untuk suatu produk. Tujuan penggunaan kemasan antara lain meliputi:

1) Sebagai pelindung isi (protection).

2) Untuk memberikan kemudahan dalam penggunaan.

3) Bermanfaat dalam pemakaian ulang (reusable).

4) Memberikan daya tarik (promotion).

5) Sebagai identitas (image) produk.

6) Distribusi (Shipping).

7) Informasi.

8) Sebagai cermin inovasi produk
3. Label merupakan bagian dari suatu produk yang menyampaikan informasi mengenai produk dan penjual.

4. Layanan-layanan pelengkap (Supplementary supplies) dapat diklasifikasikan menjadi:

1) Informasi.

2) Konsultasi.

3) Order Taking, order entry, dan reservasi.

4) Hospitality.

5) Caretaking.

6) Exception.

7) Billing.

8) Pembayaran.

9) Jaminan (Garansi).

\section{Merek}

Merek menurut American Marketing Association dalam Kotler dan Keller (2016:322), adalah sebagai nama, istilah, tanda, lambang, atau desain, atau kombinasinya, yang dimaksudkan untuk mengidentifikasikan barang atau jasa dari salah satu penjual atau kelompok penjual dan mendiferensiasikan barang atau jasa dari salah satu penjual atau kelompok penjual dan mendiferensiasikan merek dari para pesaing. 


\section{Citra Merek}

Citra merek menurut Kotler dan Keller (2009:403), adalah persepsi dan keyakinan yang dipegang oleh konsumen, seperti yang dicerminkan asosiasi yang tertanam dalam ingatan pelanggan, yang selalu diingat pertama kali saat mendengar slogan dan tertanam dibenak konsumenya. Menurut Kotler (2012:261), ada beberapa indikator yang mempengaruhi citra merek, yaitu:

1. Persepsi konsumen terhadap pengenalan produk.

2. Persepsi konsumen terhadap kualitas produk.

3. Persepsi konsumen terhadap ukuran.

4. Persepsi konsumen terhadap daya tahan.

5. Persepsi konsumen terhadap warna produk.

6. Persepsi konsumen terhadap harga.

7. Persepsi konsumen terhadap lokasi.

\section{Harga}

Menurut Kotler dan Armstrong (2012:52), mengungkapkan bahwa di dalam indikator harga terdapat beberapa unsur kegiatan utama tentang harga. Indikator tersebut meliputi :
1. Daftar harga.

2. Diskon.

3. Syarat pembayaran.

4. Potongan harga.

5. Kredit.

6. Periode pembayaran.

\section{Perilaku Konsumen}

Menurut Kotler dan Keller (2009:166), perilaku konsumen adalah studi tentang bagaimana cara individu, kelompok, dan organisasi memilih, membeli, menggunakan, mengkonsumsi dan bagaimana barang, jasa, ide, atau pengalaman untuk memuaskan kebutuhan dan keinginan mereka.

\section{Keputusan Pembelian}

Keputusan pembelian konsumen menurut Kotler \& Keller (2009:240), merupakan keputusan para konsumen dalam membentuk preferensi atas merek-merek yang ada di dalam kumpulan beberapa pilihan, konsumen juga dapat membuat keputusan untuk pembelin merek yang paling disukai.

\section{Rumusan Masalah}

Berdasarkan pada latar belakang diatas, maka rumusan masalah penelitian ini adalah:

1. Apakah terdapat pengaruh citra merek terhadap keputusan pembelian pada 
brand Jeanne Arthes

parfum.?

2. Apakah terdapat pengaruh harga terhadap keputusan pembelian pada brand Jeanne Arthes parfum.?

3. Apakah terdapat pengaruh citra merek dan harga terhadap keputusan pembelian pada brand Jeanne Arthes parfum.?

\section{Tujuan Penelitian}

1. Untuk mengetahui pengaruh citra merek terhadap keputusan pembelian pada brand Jeanne Arthes parfum.

2. Untuk mengetahui pengaruh harga terhadap keputusan pembelian pada brand Jeanne Arthes parfum.

3. Untuk mengetahui pengaruh citra merek dan harga terhadap keputusan pembelian pada brand Jeanne Arthes parfum.

\section{Hipotesis Penelitian}

Hipotesis adalah dugaan yang sifatnya sementara dan perlu dibuktikan kebenarannya. Berdasarkan latar belakang dan dasar teori diatas, penulis mengemukakan hipotesis sebagai berikut:
H1:Citra merek mempunyai pengaruh signifikan terhadap keputusan pembelian.

$\mathrm{H} 2$ :Harga mempunyai pengaruh signifikan terhadap keputusan pembelian.

H3:Citra merek dan harga mempunyai pengaruh simultan terhadap keputusan pembelian.

\section{METODE}

\section{Definisi Operasional}

1. Citra merek adalah asosiasi atau kepercayaan yang ada dalam benak konsumen untuk menjadi pembeda dari merek yang lainnya seperti lambang, desain huruf atau warna khusus. Adapun indikatornya sebagai berikut :

1. Menimbulkan rasa suka.

2. Kesan yang baik.

3. Merek yang populer.

2. Harga merupakan sejumlah uang yang dibebankan atas suatu produk atau jasa atau jumlah dari nilai yang ditukar konsumen atas manfaatmanfaat karena memiliki atau menggunakan produk. Memiliki indikator sebagai berikut :

1. Keterjangkauan harga. 
2. Adanya diskon.

3. Kesesuaian harga dengan manfaat.

3. Keputusan pembelian sebagai pemilihan suatu tindakan dari dua atau lebih pilihan alternatif. Adapun indikatornya sebagai berikut:

1. Kesesuaian dengan kemampuan keuangan.

2. Mudah di ingat.

3. Kesesuaian produk dengan keinginan.

\section{Teknik Pengumpulan Data, Populasi,} dan Sampel

Metode pengumpulan data yang digunakan pada penelitian ini adalah penelitian lapangan (observasi dan kuesioner) dan penelitian kepustakaan.

Populasi dalam penelitian ini adalah seluruh pelanggan parfum brand Jeanne Arthes MDS Mall Lembuswana Samarinda, dan dilihat dari jumlahnya termasuk dalam populasi yang tidak diketahui.

Berapa dan bagaimana diantara popilasi tersebut yang dijadikan sampel yakni dibagi berdasarkan kriteria jenis kelamin, umur dan pekerjaan.

Teknik Analisis

Alat analisis yang digunakan dalam penelitian ini adalah uji asumsi

klasik dan regresi linear berganda.

\section{HASIL DAN PEMBAHASAN}

\section{Uji Validitas}

Uji validitas digunakan untuk mengetahui kesamaan antara data yang dikumpul dengan data yang sesungguhnya terjadi pada obyek yang diteliti, sehingga dapat diperoleh hasil yang valid. Valid berarti instrument tersebut dapat digunakan untuk mengukur apa yang seharusnya diukur.

Dari analisis diperoleh :

\begin{tabular}{|c|c|c|c|c|}
\hline No & Variabel & $\mathbf{r}_{x y}$ & $\mathbf{r}_{\text {tabel }}$ & Keterangan \\
\hline \multirow[t]{4}{*}{1} & \multicolumn{4}{|c|}{ Citra Merek $\left(\mathbf{X}_{1}\right)$} \\
\hline & X1.1 & 0.918 & 0.200 & Valid \\
\hline & $\mathrm{X} 1.2$ & 0.918 & 0.200 & Valid \\
\hline & $\mathrm{X} 1.3$ & 0.608 & 0.200 & Valid \\
\hline \multirow[t]{4}{*}{2} & \multicolumn{4}{|l|}{$\operatorname{Harga}\left(X_{2}\right)$} \\
\hline & $\mathrm{X} 2.1$ & 0.746 & 0.200 & Valid \\
\hline & X2.2 & 0.944 & 0.200 & Valid \\
\hline & $\mathrm{X} 2.3$ & 0.944 & 0.200 & Valid \\
\hline \multirow[t]{4}{*}{3} & \multicolumn{4}{|c|}{ Keputusan Pembelian (Y) } \\
\hline & Y1.1 & 0.708 & 0.200 & Valid \\
\hline & Y1.2 & 0.804 & 0.200 & Valid \\
\hline & Y1.3 & 0.795 & 0.200 & Valid \\
\hline
\end{tabular}

\section{Uji Reliabilitas}

Uji reliabilitas adalah untuk mengukur sejauh mana suatu alat pengukuran dapat memberikan hasil yang reliabel bila dilakukan dalam 
waktu yang berbeda pada obyek yang sama.

\begin{tabular}{llccc} 
No & Variabel & $\mathrm{r}_{\text {alpha }}$ & $\begin{array}{c}\mathrm{r} \\
\text { kritis }\end{array}$ & $\begin{array}{c}\text { Keterang } \\
\text { an }\end{array}$ \\
\hline 1 & Citra Merek & 0.746 & 0.6 & Reliabel \\
& $\left(\mathrm{X}_{1}\right)$ & & 0 & \\
& & & & \\
\hline 2 & Harga $\left(\mathrm{X}_{2}\right)$ & 0.853 & 0.6 & Reliabel \\
& & & 0 & \\
& & & & \\
\hline 3 & Keputusan & 0.647 & 0.6 & Reliabel \\
& Pembelian (Y) & & 0 &
\end{tabular}

\section{Uji Normalitas}

Berdasarkan uji kolmogorovsmirnov diketahu bahwa nilai Asymp.Sig. (2-tailed) sebesar 0,222, karena nilai signifikansi > 0,05 maka

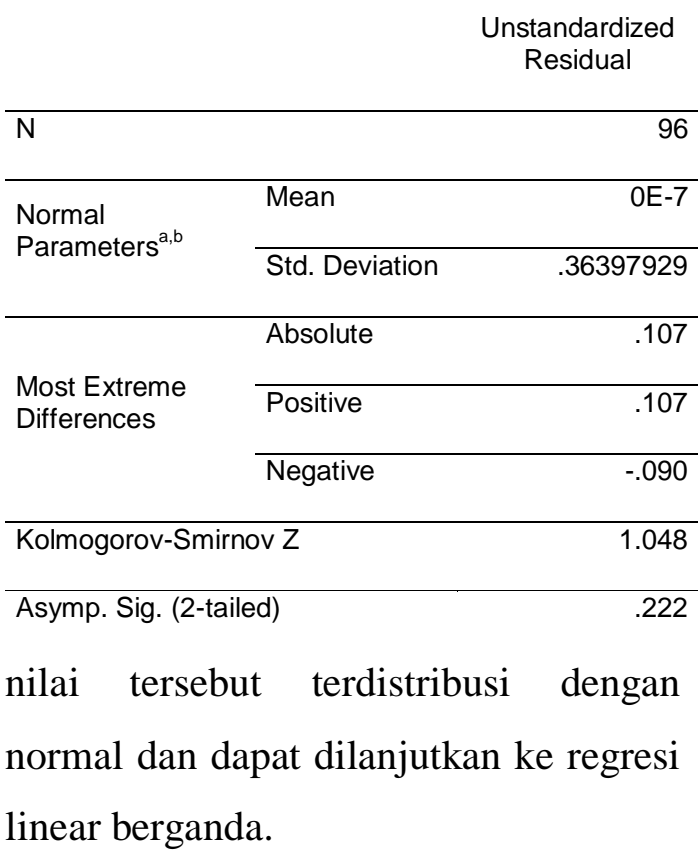

\section{Uji Linieritas}

Tujuan uji linieritas adalah untuk mengetahui hubungan antara variable bebas dan variabel terikat linier atau tidak. Kriteria pengujian linieritas adalah jika nilai signifikasi lebih kecil dari 0,05 , maka hubungan antara variabel bebas dan variabel terikat adalah linier.

\begin{tabular}{ccc} 
Variabel & Sig & Keterangan \\
\hline $\begin{array}{c}\text { Citra Merek } \rightarrow \\
\text { Keputusan Pembelian }\end{array}$ & 0,000 & Linear \\
\hline $\begin{array}{c}\text { Harga } \rightarrow \text { Keputusan } \\
\text { Pembelian }\end{array}$ & 0,000 & Linear
\end{tabular}

\section{Uji Multikolonieritas}

Pengujian multikolonieritas dilakukan untuk menguji antar variabel independen terhadap variabel dependen dapat dilakukan dengan melihat nilai Tolerance dan Variance Inflation Factor (VIF) serta besaran korelasi antar variabel independen.

\begin{tabular}{|c|c|c|c|}
\hline \multirow{2}{*}{\multicolumn{2}{|c|}{ Model }} & \multicolumn{2}{|c|}{ Collinearity Statistics } \\
\hline & & Tolerance & VIF \\
\hline \multirow[t]{4}{*}{1} & (Constant) & & \\
\hline & Citra Merek & .723 & 1.383 \\
\hline & Harga & .723 & 1.383 \\
\hline & Berdas & table & diatas \\
\hline
\end{tabular}

menjelaskan bahwa data yang ada tidak terjadi gejala multikolinearitas antara masing-masing variabel independen yaitu dengan melihat nilai VIF. Nilai VIF yang diperbolehkan hanya mencapai 10 maka data di atas dapat dipastikan tidak terjadi gejala multikolinearitas. Karena data di atas menunjukan bahwa nilai tolerance lebih besar dari 0,10 dan nilai VIF lebih kecil dari 10 keadaan seperti itu 
membuktikan tidak terjadinya multikolinearitas.

\section{Uji Heteroskedastisitas}

Uji heteroskedastisitas bertujuan untuk menguji dalam model regresi terjadi ketidaksamaan varians dari residual satu pengamatan ke pengamatan yang lain. Cara untuk mengetahui terjadi heteroskedastisitas atau tidak yaitu dengan melihat Grafik Plot antara nilai prediksi variabel dependen yaitu ZPRED dengan residualnya SRESID. Tidak terjadi heteroskedastisitas yaitu apabila tidak ada pola yang jelas, serta titik-titik menyebar di atas dan di bawah angka 0 pada sumbu Y.

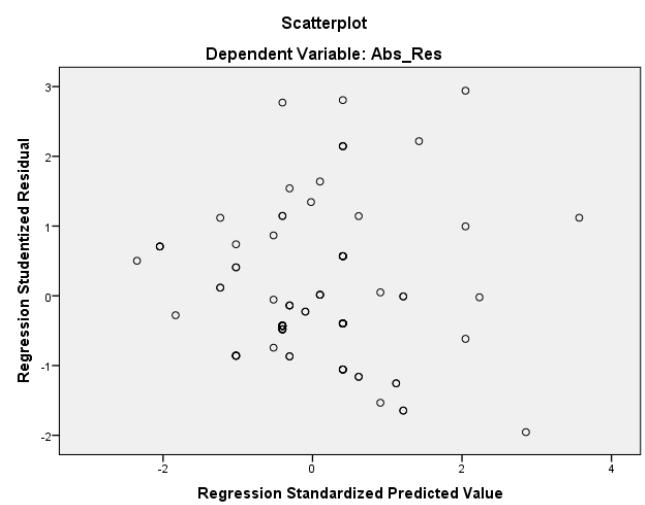

Dari grafik scatterplot yang di atas dapat dilihat bahwa titik-titik menyebar secara acak, serta tersebar baik di atas maupun dibawah angka nol pada sumbu Y. Hal ini dapat disimpulkan bahwa tidak terjadi heteroskedastisitas pada model regresi.

\section{Uji Autokorelasi}

Uji autokorelasi bertujuan menguji apakah dalam model regresi linear ada korelasi antara kesalahan pengganggu pada periode $t$ dengan kesalahan pengganggu pada periode $\mathrm{t}-1$. Uji auotokorelasi bertujuan untuk mengetahui apakah ada korelasi antara anggota serangkaian data observasi yang diuraikan menurut waktu (timeseries) atau ruang (cross section).

\begin{tabular}{|c|c|c|c|c|c|}
\hline \multicolumn{6}{|c|}{ Model Summary ${ }^{\mathfrak{D}}$} \\
\hline Model & $\mathrm{R}$ & $\begin{array}{c}\mathrm{R} \\
\text { Squar } \\
\mathrm{e}\end{array}$ & $\begin{array}{c}\text { Adjust } \\
\text { ed R } \\
\text { Squar } \\
\text { e }\end{array}$ & $\begin{array}{l}\text { Std. Error } \\
\text { of the } \\
\text { Estimate }\end{array}$ & $\begin{array}{l}\text { Durbin- } \\
\text { Watson }\end{array}$ \\
\hline 1 & .677 & .458 & .446 & .368 & 1.381 \\
\hline
\end{tabular}

Uji autokorelasi dapat dilakukan dengan menggunakan uji Durbin Watson. Syarat tidak terjadi autokorelasi adalah $1<\mathrm{DW}<3$. Berdasarkan output hasil uji autokorelasi menunjukkan bawha pada uji autokorelasi diperoleh nilai uji Durbin-Watson adalah 1,381. Angka ini lebih besar dari 1 dan lebih kecil dari 3 . Secara ringkas $1<1,381<3$. Karena DW berada di antara dua angka batasan autokorelasi, maka hal ini menunjukkan bahwa pada model regresi tidak terdapat autokorelasi.

\section{Regresi Linier Berganda}

Penelitian ini menggunakan Analisis Regresi Linier Berganda 
(Multiple Regression Analysis) yang bertujuan untuk mengetahui pengaruh variabel citra merek $\left(\mathrm{X}_{1}\right)$, harga $\left(\mathrm{X}_{2}\right)$ terhadap keputusan pembelian (Y).

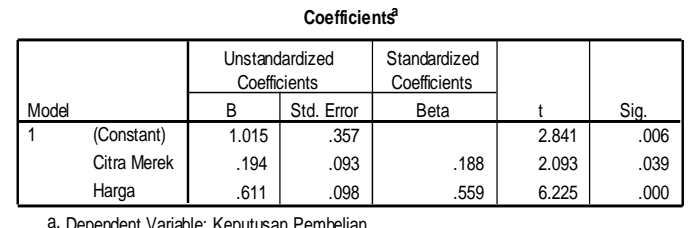

Berdasarkan tabel di atas diperoleh persamaan regresi citra merek $\left(\mathrm{X}_{1}\right)$, harga $\left(\mathrm{X}_{2}\right)$, terhadap keputusan pembelian (Y) adalah sebagai berikut:

$Y=a+b_{1} X_{1}+b_{2} X_{2}+e$

$\mathrm{Y}=1,015+0,188 \mathrm{X}_{1}+0,559 \mathrm{X}_{2}+\mathrm{e}$

\section{Pengaruh Citra Merek $\left(\mathbf{X}_{1}\right)$} terhadap Keputusan Pembelian

(Y) $b_{1}=0,188$

Berdasarkan hasil analisis di atas bahwa variabel citra merek $\left(\mathrm{X}_{1}\right)$ berpengaruh positif dan signifikan terhadap keputusan pembelian (Y). Hal ini dapat diartikan bahwa citra merek $\left(\mathrm{X}_{1}\right)$ berpengaruh terhadap keputusan pembelian (Y) sebesar 0,188. Hal ini menunjukkan bahwa pengaruh citra merek terhadap keputusan pembelian sebesar $18,8 \%$ dan $\sqrt{1-0,188}$ berhubungan dengan faktor lain yang tidak termasuk dalam analisis regresi ini.
2. Pengaruh Harga $\left(\mathbf{X}_{2}\right)$ terhadap Keputusan Pembelian (Y) $\mathbf{b}_{2}=$ 0,559

Berdasarkan hasil analisis di atas bahwa variabel harga $\left(\mathrm{X}_{2}\right)$ berpengaruh positif dan signifikan terhadap keputusan pembelian (Y). Hal ini dapat diartikan bahwa harga $\left(\mathrm{X}_{2}\right)$ berpengaruh terhadap keputusan pembelian (Y) sebesar 0,559. Hal ini menunjukkan bahwa pengaruh harga terhadap keputusan pembelian sebesar $55,9 \%$ dan $\sqrt{1-0,559}$ berhubungan dengan factor lain yang termasuk dalam analisis regresi ini.

\section{Uji $\mathbf{R}^{2}$}

Untuk menentukan seberapa besar variabel independen dapat menjelaskan variabel dependen, maka perlu diketahui nilai koefisien determinasi (Adjusted R-Square). Adapun hasil uji determinasi Adjusted $\mathrm{R} 2$

\begin{tabular}{lrrrr}
\hline $\begin{array}{l}\text { Mod } \\
\text { el }\end{array}$ & $\mathrm{R}$ & $\begin{array}{c}\mathrm{R} \\
\text { Square }\end{array}$ & $\begin{array}{c}\text { Adjusted R } \\
\text { Square }\end{array}$ & $\begin{array}{c}\text { Std. Error of } \\
\text { the } \\
\text { Estimate }\end{array}$ \\
\hline 1 & $\begin{array}{r}.67 \\
7^{\mathrm{a}}\end{array}$ & .458 & .446 & .368 \\
& & & & \\
\hline
\end{tabular}

Berdasarkan tabel di atas diketahui nilai koefisien determinasi $\left(\mathrm{R}^{2}\right)$ berada diantara 0 dan 1 atau $0<\mathrm{R}^{2}$ 
< $1 . \mathrm{R}^{2}$ sebesar $0,458(45,8 \%)$. Dengan nilai koefisien determinasi sebesar 0,458 ini menunjukan bahwa dengan menggunakan model regresi yang didapatkan dimana variabel independen yaitu citra merek $\left(\mathrm{X}_{1}\right)$ dan harga $\left(\mathrm{X}_{2}\right)$, memiliki pengaruh terhadap variabel keputusan pembelian (Y) sebesar $45,8 \%$. Sedangkan sisanya $\sqrt{1-0,458}$ berhubungan dengan faktor atau variabel lain yang tidak termasuk dalam analisis regresi ini.

\section{Uji F}

Pengujian ini digunakan uji $\mathrm{F}$, yaitu dengan membandingkan nilai probabilitas (sig-F), dengan taraf signifikasi 0,05 , dan perbandingan antara $\mathrm{F}_{\text {hitung }}$ dengan $\mathrm{F}_{\text {tabel. }}$ Jika nilai $\mathrm{P}<$ 0,05 maka Ho ditolak, dan Ha diterima, sebaliknya jika $\mathrm{P}>0,05$ maka Ho diterima, dan Ha ditolak. Kemudian jika $\mathrm{F}_{\text {hitung }}<\mathrm{F}_{\text {tabel }}$ maka Ho ditolak, dan $\mathrm{Ha}$ diterima, begitu sebaliknya jika $F_{\text {hitung }}>$ $F_{\text {tabel }}$ maka Ho diterima, dan Ha ditolak.

\begin{tabular}{|c|c|c|c|c|c|c|}
\hline \multicolumn{7}{|c|}{ ANOVA } \\
\hline Mo & & $\begin{array}{l}\text { Sum of } \\
\text { Squares }\end{array}$ & $d f$ & Mean Square & $\mathrm{F}$ & Sig. \\
\hline \multirow[t]{3}{*}{1} & Regression & 10.639 & 2 & 5.320 & 39.308 & $.000^{\mathrm{a}}$ \\
\hline & Residual & 12.586 & 93 & .135 & & \\
\hline & Total & 23.225 & 95 & & & \\
\hline
\end{tabular}

Hasil uji $F$, nilai $F_{\text {hitung }}$ 39,308 lebih besar dari $\mathrm{F}_{\text {tabel }}$ 3,09 dengan nilai signifikan 0,000 lebih kecil dari 0,05 sehingga signifikan dan hipotesa diterima. Hal yang menyebutkan terdapat pengaruh yang positif dan signifikan antara variabel citra merek $\left(\mathrm{X}_{1}\right)$ dan harga $\left(\mathrm{X}_{2}\right)$ terhadap keputusan pembelian (Y). Hal ini menunjukkan bahwa model yang diajukan layak di gubakan untuk memprediksi adanya pengaruh citra merek dan harga terhadap keputusan pembelian.

\section{Uji T}

Uji $\mathrm{T}$ menunjukkan suatu pengaruh antara variabel independen terhadap variabel dependen yang diuji pada tingkat signifikansi 0,05 .

\begin{tabular}{llrr}
\multicolumn{2}{l}{ Model } & $\mathrm{T}$ & \multicolumn{1}{l}{ Sig. } \\
\hline $1 \quad$ (Constant) & 2.841 & 0.006 \\
& Citra & 2.093 & 0.039 \\
& Merek & 6.225 & 0.000 \\
& Harga & &
\end{tabular}

Menurut hasil perhitungan diperoleh bahwa $t_{\text {hitung }}$ variabel citra merek lebih besar dari pada $t_{\text {tabel }}$ dengan taraf signifikan 5\% sebesar 0,039. Jadi citra merek $t_{\text {hitung }}>t_{\text {tabel }}(2,093>1,661)$, sehingga Ha diterima, dari analisis tersebut dapat disimpulkan bahwa menerima Ha yang menyebutkan ada pengaruh positif dan signifikan antara citra merek $\left(\mathrm{X}_{1}\right)$ terhadap keputusan pembelian (Y).

Hasil perhitungan diperoleh

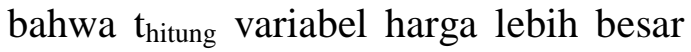
dari pada $t_{\text {tabel }}$ dengan taraf signifikan 
$5 \%$ sebesar 0,000 . Jadi harga $t_{\text {hitung }}>$ $\mathrm{t}_{\text {tabel }}(6,225>1,661)$, sehingga $\mathrm{Ha}$ diterima, dari analisis tersebut dapat disimpulkan bahwa menerima Ha yang menyebutkan ada pengaruh positif dan signifikan antara harga $\left(\mathrm{X}_{2}\right)$ terhadap keputusan pembelian (Y).

Hasil penelitian ini sesuai dengan hasil penelitian yang dilakukan oleh Fristiana (2012) menunjukkan bahwa secara simultan citra merek dan harga berpengaruh positif terhadap keputusan pembelian. Berbeda dengan temuan Rossietal (2015) juga menyatakan bahwa produk berpengaruh terhadap niat pembelian dan citra merek tidak berpengaruh terhadap niat pembelian.

\section{PEMBAHASAN}

\section{Pengaruh Citra Merek terhadap} Keputusan Pembelian

Berdasarkan uji $\mathrm{t}$ maka dapat diketahui bahwa $t_{\text {hitung }}$ variabel citra merek lebih besar dari pada $t_{\text {tabel }}$ dengan taraf signifikan 5\% sebesar 0,039. Jadi harga $t_{\text {hitung }}>t_{\text {tabel }}(2,093>1,661)$, sehingga Ha diterima, dari analisis tersebut dapat disimpulkan bahwa menerima Ha yang menyebutkan ada pengaruh positif dan signifikan antara citra merek terhadap keputusan pembelian.
Jadi dengan citra merek (brand image) Jeanne Arthes Parfum yang bagus tersebut maka dapat meningkatkan keputuan pembelian konsumen.

\section{Pengaruh Harga Terhadap}

\section{Keputusan Pembelian}

Berdasarkan uji t maka dapat diketahui bahwa $t_{\text {hitung }}$ variabel harga lebih besar dari pada $t_{\text {tabel }}$ dengan taraf signifikan 5\% sebesar 0,000. Jadi harga $t_{\text {hitung }}>t_{\text {tabel }}(6,225>1,661)$, sehingga Ha diterima, dari analisis tersebut dapat disimpulkan bahwa menerima Ha yang menyebutkan ada pengaruh positif dan signifikan antara harga terhadap keputusan pembelian. Artinya, harga pada Brand Jeanne Arthes Parfum baik tinggi maupun rendah tidak mempengaruhi pengambilan keputusan konsumen untuk membeli Brand Jeanne Arthes Parfum. Harga dapat menjadi alat ukur nilai dari sebuah produk. Untuk itu perusahaan harus dapat menentukan harga dengan tepat sehingga dapat diterima oleh masyarakat atau konsumen.

Pengaruh Simultan antara Citra Merek dan Harga terhadap Keputusan Pembelian.

Citra merek dan harga secara simultan berpengaruh positif dan 
signifikan terhadap keputusan pembelian. Hal ini dapat dilihat dari hasil uji $F$, nilai $F_{\text {hitung }}$ 39,308 lebih besar dari $F_{\text {tabel }} 3,09$ dengan nilai signifikan 0,000 lebih kecil dari 0,05.

\section{KESIMPULAN DAN SARAN}

\section{Kesimpulan}

Berdasarkan hasil analisis data mengenai pengaruh citra merek dan harga terhadap keputusan pembelian pada Brand Jeanne Arthes Parfum PT.

Matahari Department Store Mall Lembuswana Samarinda, dapat disimpulkan sebagai berikut:

1. Ada pengaruh positif dan signifikan antara citra merek terhadap keputusan pembelian pada Brand Jeanne Arthes Parfum PT. Matahari Department Store Mall Lembuswana Samarinda.

2. Ada pengaruh positif dan signifikan antara harga terhadap keputusan pembelian pada Brand Jeanne Arthes Parfum PT. Matahari Department Store Mall Lembuswana Samarinda.

3. Ada pengaruh positif dan signifikan antara citra merek dan harga secara simultan berpengaruh terhadap keputusan pembelian pada Brand Jeanne Arthes Parfum PT. Matahari
Department Store Mall

Lembuswana Samarinda.

\section{Saran}

Berdasarkan hasil analisis data mengenai pengaruh citra merek dan harga terhadap keputusan pembelian pada Brand Jeanne Arthes Parfum PT. Matahari Department Store Mall Lembuswana Samarinda, maka dapat disarankan sebagai berikut:

1. Bagi peneliti selanjutnya dapat dilakukan dengan merek produk lain sehingga yang teridentifikasi lebih banyak lagi.

2. Bagi peneliti selanjutnya dapat dilakukan penelitian dengan variabel bebas lain, seperti bauran pemasaran, pengaruh budaya dan sosial, sehingga variabel yang mempengaruhi keputusan pembelian dapat teridentifikasi lebih banyak lagi.

\section{DAFTAR PUSTAKA}

Alma, Buchari. 2011. Manajemen Pemasaran dan Pemasaran Jasa. Bandung: Alfabeta.

Fitriani, Eni. 2017. "Pengaruh Kualitas Produk dan Harga Terhadap Keputusan Pembelian Produk Kosmetik Wardah pada Mahasiswi Fakultas Ekonomi dan Bisnis Universitas Halu Oleo". eJournal Ekonomi dan Bisnis. 
Fristiana, D.A. 2012. "Pengaruh Citra Merek dan Harga terhadap Keputusan Pembelian pada Ramai Swalayan Peterongan Semarang". eJurnal Ilmu Administrasi Bisnis. 1. 1-9.

Hasibuan, Malayu S.P. 2009. Manajemen: Dasar, Pengertian, dan Masalah. Edisi revisi. Jakarta: Bumi Aksara.

Kotler, Philip. 2012. Manajemen Pemasaran Perspektif Asia. Buku Dua. Edisi Pertama. Yogyakarta: Andy.

Kotler, Philip dan Garry Armstrong. 2012. Prinsip-prinsip Pemasaran Jilid 1. Edisi 1. Jakarta: Erlangga.

Kotler, Philip dan Keller, Kevin L. 2009. Manajemen Pemasaran.
Jilid 1. Edisike 13. Jakarta: Erlangga.

2016. Marketing Managament. $15^{\text {th }}$ Edition. Pearson Education. Inc.

Mariana. 2015. "Pengaruh Kualitas Produk Dan Harga Terhadap Keputusan Pembelian Produk Pada Industri UKM Amplang UD. Sinar Rejeki Di Samarinda". eJournal Ilmu Administrasi Bisnis.

Swasta, Basu. 2010. Manajemen Pemasaran: Analisa dan Perilaku Konsumen. Yogyakarta: BPFE.

Tjiptono, Fandy. 2010. Strategi Pemasaran. Edisi 2. Yogyakarta: Andi Offset. 